\title{
Social Networking Services: A New Platform for Participation in Government Programmes and Policies among Nigerian Youths
}

\author{
Ifeanyi J. Ezema \\ Department of Information Science \\ University of South Africa, South Africa \\ Nnamdi Azikiwe Library, University of Nigeria, Nigeria \\ ezemaji@unisa.ac.za, ifeanyi.ezema@unn.edu.ng \\ Christian S. Ezeah \\ Nnamdi Azikiwe Library, \\ University of Nigeria, Nigeria \\ christian.ezeah@unn.edu.ng \\ Benedict N. Ishiwu \\ Nnamdi Azikiwe Library, \\ University of Nigeria, Nigeria \\ ishiwub@gmail.com
}

\begin{abstract}
Background. Many youths have adopted social networking media for communication with friends, family members and the general public.

Objective. This study examined the participation of youths in government programmes and policies in Nigeria using social networking media.

Method. A total of 200 Nigerian youths were sampled from four Nigerian universities. A structured questionnaire was administered to the respondents and 190 (95\%) were properly completed.

Results. The major social networking media used by Nigerian youths are Facebook, Google+, 2go, Skype and Twitter. They are mainly used for "social interaction," "study, teaching and learning," "information dissemination" and "research and academic purposes." The youths rarely use these sites to participate in governance. The major challenges faced in the use of social networking are a lack of control on the activities of the users, power failures, the high cost of accessing the Internet, and poor Internet connectivity. Nigerian youths employ social networking to aggregate their views in government policies such as environmental issues, health, power supply, education, human capital development and security issues. The youths believe that social networking has improved participatory democracy in education and human capital development, health, environmental issues, power supply and budget monitoring. Conclusion. Social networking has dramatically improved the participation of youths in national discourses. The results of the study can serve as a useful guide on the use of social networking services for participatory democracy by youths in developing countries.
\end{abstract}




\section{INTRODUCTION}

In Nigeria, the long period of military dictatorship denied citizens the opportunity of participation in government policies and programmes. This resulted in the growth and development of the Nigerian economy without a corresponding improvement in the overall welfare of Nigerian citizens (National Planning Commission, 2011). With the return to civil democracy in 1999, greater opportunities were offered to the citizens to participate in government activities. President Abraham Lincoln has defined democracy in his Gettysburg address as "government of the people by the people and for the people" (Epstein, 2011). This implies participation of the people in issues that concern them.

The issue of participation is critical to the success of every democratic government globally. In the foreword to the World Bank Learning Group's publication on participation, the idea of participation was defined as a "process through which stakeholders influence and share control over development initiatives and the decision and resources which affect them" (World Bank, 1996, p. xi). The African Community Publishing and Development Trust (2006, p. 5) views participation as being involved in a programme "as individual and as a community in decision making at each step of development process."

This definition recalls Arnstein's concept of the ladder of participation developed in 1969, which listed eight levels of citizen participation. Burns, Hambleton and Hogett (1994) later modified Arnstein's ladder of participation and proposed a ladder of citizen power which enumerated factors that encourage or discourage citizen participation. This theory hinges the success or failure of citizen participation on information available to the citizen and the nature of consultations deployed. It is upon this theory that this present study is framed. This is because social networking media are all about providing adequate and speedy information to the citizens.

Participation can be political or social (Gaventa \& Valderrama, 1999); it can also be active or passive (Chikerema, 2013). Political participation is concerned with "taking part in the process of formulation, passage and implementation of public policies" (Parry, Mosley \& Day, 1992, p. 16); while social participation involves the community or social sectors (Gaventa \& Valderrama, 1999). Participation can also be voluntary or coerced. Coerced participation may not entail just the use of force, but imposition of a little fine or sometimes the denial of privileges to ensure compliance, while voluntary participation deals with the individual's willingness to be a part of government programmes and policies (Milakovich, 2010). Whatever form of citizen participation is adopted, the purpose is to ensure active citizen participation in the programmes of the government. Milakovich identifies seven specific purposes of participation, namely: providing information to citizens, receiving information from or about citizens, improving public decision processes, enhancing public acceptance of government programmes, altering the pattern of political power and allocation of resources, protecting individual and minority rights, and delaying or avoiding difficult public policy decisions.

These specific purposes of participation are intended to provide an enabling environment that would improve the living conditions of the people through articulation and implementation of good public policies. This is typical of the immediate past President of Nigeria, Goodluck Jonathan's administration which intended to prepare the country as a key player in the global socio-economic platform. The key objective of the government was the transformation of the country into a full democratic country where every citizen would have opportunities to make contributions in the process of governance. Therefore, the 
administration's major focus was to reposition the country to compete favourably in the global environment.

The transformation project required the full participation of the citizens, particularly the youths who constituted a large proportion of the country's human capital. This was important because earlier development plans of the government for poverty reduction such as the Green Revolution, National Economic Empowerment Development Strategy (NEEDS), State Economic Empowerment Development Strategy (SEEDS), Vision 2010, Millennium Development Goals (MDG) among others did not result in significant impact on poverty reduction and sustainable development (National Planning Commission, 2011). This was because youths were not given the opportunity to make inputs in the programme. At the inception of the administration of Dr. Goodluck Jonathan in Nigeria, the government came up with a seven point agenda for the transformation of the country:

1. Economic transformation

2. Education/ health

3. Power supply

4. Agriculture (food security)

5. Water and sanitation

6. Physical infrastructure / transportation

7. Good governance, monitoring and evaluation.

Some government policies and programmes attracted more public opinion. Usually, the youths present their opinions through the mass media, such as radio, television and the print media. The media are obviously critical to the success of any democratic government. The government uses the media to disseminate information about its programmes and policies, and the citizens express their opinions through it. Radio and television have provided the global community with efficient communication channels since the nineteenth century. However, developments in information and communication technology (ICT) have provided new communication channels for meaningful contribution to government policies and programmes.

With the development of Web 2.0, the global information environment improved radically as relatives, colleagues and friends engage in online chats and online business using social networking services that support the building of social relations among people with shared interests, activities, backgrounds or real life connections. Ellison and Boyd (2007) characterised social networking services as Web-based services that allow individuals to construct profiles, display user connections, and search and traverse within that list of connections. Social networking represents an evolution of the "Internet from a top-down information-provider model, to one which is very much in the hands of the individual end user and communities of end users. A key element of Web 2.0 is that users are the main figures in generating and shaping content." (Alexa Website ranking, 2007, cited in Watson, 2008).

The Canadian Nurses Association (2012) described social networking as a group of "Internet-based application and technologies that allow users to have the same kind of 'realtime' conversations they might have with friends or neighbours with virtual friends from around the globe." Safranek (2012) noted that social networking breaks the traditional socioeconomic barrier because "you don't have to be somebody to be somebody" when using social media. It involves the use of collaborative technologies such as smart phone, personal computers and iPads, which allow individuals to interact with one another through the Web. Davies (2010) saw social networking as a Web-based and mobile application that allows individuals or organisations to create and share new user-generated or existing content in the 
digital environment through multi-way communication. Globally, social networking has been used by youths to make contributions in government policies and engage equally in political mobilisation. For example, the Society for New Communication Research (2009) and Medimorec, Parycek and Schossböck (2011), in separate studies, reported that in the 2008 US presidential election, social networking played a key role in deciding the winner of the election. Similarly, Safranek (2012) revealed that the recent revolution and changes in the Middle East, which engulfed Iran, Tunisia, Egypt, Lebanon, Syria and Libya, were influenced by social networking comments on the policies of governments in the region.

In Nigeria, citizens have also increasingly relied on the use of social networking media to respond to government policies and programmes. Social networking media enable interactive communication with government officials on an electronic platform. Medimorec, Parycek and Schossböck (2011) referred to this as e-participation. In several modern democracies, many of the government policies and programmes are youth-based since they constitute a large percentage of the population and active workforce of their countries (National Bureau of Statistics, 2010). Consequently, youths are very important in active eparticipation in Nigeria because they constitute a large proportion of Internet users. Studies have confirmed that Nigerian youths are active users of social networking media (Nwafor, Igbokwe \& Ugwuanyi, 2012; Ekwelem, Okafor \& Ukwoma, 2012; Asogwa \& Ojih, 2013). However, it is not clear whether the activities and programmes of government are part of their discourse in the social networking sites. This paper examines the extent of participation of Nigerian youths on the programmes of the government using social networks.

Specifically, this study seeks to:

1. identify the social networking media Nigerian youths use;

2. ascertain how often these sites are used;

3. determine the purpose of using social networking media by Nigerian youths;

4. ascertain how often youths participate in government programmes and policies using social networking media;

5. determine the extent social networking media have improved government programmes and policies in Nigeria;

6. ascertain the challenges of using social networking media in Nigeria.

\section{LITERATURE REVIEW}

There have been several research studies on social networking media, both on the theoretical approaches as well as on the practical application of the new media. Bryer and Zavatarro (2001) noted that social networking involves the use of modern technologies to facilitate social interactions, make collaborations possible between individuals and organisations, and enables deliberation across stakeholders. Junco, Heibergert and Loken (2010) saw social networking as a platform and practice that supports collaboration, community building and information sharing and citizen participation in the decision-making process. Goad, Mooney and Bruns (2008) however posited that social networking services use the World Wide Web for radical transformation of the society where the populace are no longer passive in government activities. In some developed nations where social media are used for egovernance, ordinary citizens have the opportunity to make inputs in development policies through active participation.

Social networking media provide opportunities for citizens to participate on electronic platforms, which Medimorec, Parycek and Schossböck (2011) referred to as e-participation. E-participation is a form of online involvement in the process of governance. According to 
Macintosh (2006), e-participation is the use of ICT in enhancing political participation of citizens. Milakovich (2010) presented the Internet as a tool for increased citizen participation in the political environment. According to Milakovich, unlike the other mass media, social networking media provide two-way communication channels which enhance the feedback process and encourage interaction among citizens and public servants. It is this interactive nature of social networking media that creates unique and effective e-participation. Political leaders also adopt social networking media to maintain closeness and transparency with their citizens (Aharony, 2012). A recent study by Khan, Yoon, Kim and Park (2014) explored Twitter use among the Korean Central government. They found that government Twitter use did not motivate citizens, but government-to-government relationships were enhanced.

Apart from government functionaries, the number of social network users is increasing every minute. Burkhardt (2010, cited in Ekwelem, Okafor \& Ukwoma, 2012) reported over 300 million active users of Facebook, over 100 million active users of LinkedIn, over 5 billion images on Flickr, and more than 7000 tweets per second. Anjum (2014) reported that Facebook had over 1.15 billion users, LinkedIn over 238 million active users, and Twitter over 500 million users with more than 20 million fake accounts. Topper (2007) and Thelwall (2008) reported that more than half (55\%) of all online youths from ages 12 to 17 used online social networking media with MySpace and Facebook dominating the media. These statistics are testimony to the ever-increasing need and use of social networking globally.

Similarly, Anderson (2005) described social networking media as a class of network tools that support and encourage individuals to learn together while retaining individual control over time, space, presence, activity, identity and relationship. Another study by Watson (2008) found that health-related electronic discussion forums and blogs had the potential of improving the health and social care of users. He regretted however that many health and social work professionals were not adequately tapping into these opportunities. A recent report published by the Canadian Nurses Association (2012) argued that social networking media provided nurses a sound platform to improve patient care, minimize health and social inequalities, and improve healthcare delivery. The report however cautioned that as nurses explored opportunities provided by social media, ethical practices must not be sacrificed. Lenhart, Purcell and Smith (2010) also noted that social networking could be used to transform the delivery of education in line with international best practices.

The Society for New Communication Research (2009, p. 4) noted that "a recordbreaking 46 percent of Americans used the Internet, email, or cell phone text messaging to get news about the [US election] campaigns, share their views, and mobilize others." The report noted that 35 percent of Americans watched political videos online and 10 percent used social networking sites such as MySpace and Facebook to learn more about the race. These are indications of increasing use of social networking services in participation in elections as compared to before. Daou (2008) remarked on his blog that "virtually every online venue that played a role in the 2008 race provided a platform for public dialogue. Blogs, boards, news sites, YouTube, Twitter, and social networks large and small were inundated with millions of individual comments, the aggregate effect of which was to determine how voters viewed the candidates and the race." Many observers of the 2008 and 2012 U.S. Presidential elections and authors such as Medimorec, Parycek and Schossböck (2011) and Bronstein (2013) believed that social media as new platforms for communication had tremendous influence in the election campaigns.

Virkus (2008) was of the view that social networking services help to promote the benefits of working cooperatively by offering tools that facilitate the aggregation and organisation of knowledge, while at the same time demonstrating the diversity of individual 
research interest that enhance learning. Adeyemi (2012, p. 11) noted that "youth on daily basis use desktop computers, laptops, e-readers, tablets, and cell phones to actively engage in social networking, text messaging, blogging, content sharing, online research activities online learning and much more for learning, research and making contributions in government policies." Abonu (2012) also investigated the use of different social networking services by the youths, their attitudes, perceptions and the reasons for the usage. He found that social networking services were used for social engagement, relationship building, employment opportunities and business purposes. The services were also used for academic and research purposes as well as political campaigns. Similarly, Kim, Lee and Elias (2015) found that personal factors such as information self-efficacy, positive social outcome expectations and sharing predict interactions on social media.

Pettit, Salazar and Dagron (2009) examined the link between organisational culture and social networking so as to predict whether social networking tools were capable of reshaping and revitalising the brand and culture of an organisation, and enhance levels of employee productivity and satisfaction. They found that employees' competencies improve as they share ideas, views and information with friends who are experts in the business area that boosts their productivity. It is also likely that the use of social networking among youths would improve government policies and programmes, particularly those that directly impact them.

As Brennan (2006) and University of Illinois at Urbana-Champaign (2007) have noted, the adoption of social networking media such as Facebook is increasing in diverse populations, and this has made life better for individuals and society as a whole. Positive outcomes from these technologies such as jobs found through LinkedIn or political activities organised via Facebook are well known. Similarly, Akindehin and Akindehin (2011) investigated the online social networking practices of some undergraduates at the University of Ibadan, Nigeria, and found that exposure to and competence in online social networking practice affects the performance of students. They recommended that in order to make classroom instructional events relevant to the real world of students, counselors should establish good relationships with students through online social network sites to complement classroom learning activities.

Another study by Ramanigopal, Palaniappa and Hemalatha (2012) examined the problems and prospects of social networking media and found several merits of social networking but cautioned that people should be very careful in using them since many have deployed it for cyber-crime (Sund, 2007). There have also been incidents of pornographic images posted on social networking sites. For example, in early 2012 some undergraduate students of Abia State University, Uturu Nigeria, raped and posted the picture of their victim on Facebook (Adesiyan, 2012). Many social network users continue to complain of postings of obscene images and write-ups on social networking sites. These practices erode African cultural values and expose young ones to high-risk behaviours. Unregulated use of social networking media has made countries such as the United States to enact Acts to protect the public from cyber bullying (Hanley, n.d).

In developing countries, social networking has several challenges that impede its full utilisation. There have been several reports of the challenges in Africa, particularly in Nigeria (e.g., Ezeani \& Ezema, 2011; Ezema, 2011; Ezema \& Ugwu, 2013). Ezeani and Ezema (2011) reported that inadequate power supply, poor Internet bandwidth and lack of experienced personnel slowed down the digitisation project at the University of Nigeria, while Ezema (2011) reported that similar factors affected the full implementation of open access institutional repositories in Nigeria. Ezema and Ugwu (2013) found irregular power supply 
and low Internet bandwidth as major challenges in the adoption of electronic theses and dissertations in Nigeria university libraries. By extension, some of these factors equally impede the use of social networking services among Nigerian youths.

\section{METHOD}

A descriptive research design was employed in the study. A descriptive study seeks to identify attributes of a particular phenomenon based on the opinion of a given population, or the exploration of correlation between two or more phenomena. This is usually achieved through the use of instruments such as interviews, questionnaires or observation checklists (Creswell, 2003; Williams, 2007). This study was conducted in the southeast region of Nigeria using students in four universities in the region. Students were chosen because they constituted a large proportion of Nigerian youths, and it was observed that they used the Internet and social media more than other categories of Nigerian youths. The universities studied were purposively sampled. They were Abia State University, Uturu, Nnamdi Azikiwe University, Awka, Ebonyi State University, Abakiliki, and University of Nigeria, Nsukka. Fifty students were randomly sampled from each of the university, which gave a total sample size of 200 youths. The instrument used for data collection was a structured questionnaire with questions employing a four-point Likert scale. It consisted of two sections: section A was concerned with the personal data of the respondents, while section B contained items on social networking and government programmes and policies, with six clusters in relation to the objectives of the study. The questionnaires were administered directly to the respondents during research visits to the universities. One hundred and ninety students, representing $95 \%$ of the respondents properly completed the questionnaires, and these were used in the data analysis.

Data on the demographic profile of the respondents and first research objective were analysed using frequencies and percentages while data collected in the other sections were analysed using mean and standard deviation. A mean of 2.50 and above was considered positive while a mean of 2.49 and below showed disagreement with the item of the instrument and therefore was considered negative.

\section{RESULTS}

From Table 1, it is evident that females constituted the greater percentage of the respondents (about 57\%). A majority of the respondents (67\%) were in the age range of 16-25 years, while $20 \%$ were in the $26-30$ range, and $13 \%$ above 30 years. The respondents were fairly evenly distributed among the academic disciplines, with a slightly higher proportion in the humanities, and a slightly lower proportion in the engineering and physical sciences. The respondents were also evenly distributed across the four years of undergraduate education, with a small percentage (6\%) above the 400 level (mainly from engineering and biomedical sciences).

Table 2 reveals that 180 of the respondents $(94.7 \%)$ used Facebook, followed by Google+ with 171 respondents (90\%), 2go with 160 respondents (84\%), Skype with 140 (74\%), and Twitter with 137 (72\%). Flixster, Flickr, Fledgewing, Habbo, MyLife and Students circle network were not used by Nigerian youths. 
Table 1. Demographic profile of the respondents

\begin{tabular}{llll}
\hline Categories & Items & Frequency & Percent \\
\hline Sex & Male & 81 & 42.6 \\
& Female & 109 & 57.4 \\
& Total & $\mathbf{1 9 0}$ & $\mathbf{1 0 0 \%}$ \\
\hline \multirow{5}{*}{ Age Range } & $16-20$ yrs & 76 & 40.0 \\
& $21-25$ yrs & 51 & 26.8 \\
& $26-30$ yrs & 38 & 20.0 \\
& Above 30 yrs & 25 & 13.1 \\
& Total & $\mathbf{1 9 0}$ & $* \mathbf{9 9 . 9 \%}$ \\
\hline \multirow{5}{*}{ Discipline } & Humanities & 37 & 19.5 \\
& Social Sciences & 34 & 17.9 \\
& Biomedical Sciences & 32 & 16.8 \\
& Engineering & 27 & 14.2 \\
& Physical Sciences & 28 & 14.7 \\
& Education & 32 & 16.8 \\
& Total & $\mathbf{1 9 0}$ & $* \mathbf{9 9 . 9 \%}$ \\
\hline \multirow{5}{*}{ Year of Study } & 100 level & 42 & 22.0 \\
& 200 level & 44 & 23.2 \\
& 300 level & 45 & 23.7 \\
& 400 level & 47 & 24.8 \\
& Above 400 level & 12 & 6.3 \\
& Total & $\mathbf{1 9 0}$ & $\mathbf{1 0 0 \%}$ \\
\hline
\end{tabular}

*Not up to $100 \%$ because of rounding.

Table 2. Social networks used by the youths

\begin{tabular}{|c|c|c|c|}
\hline Rank & Items & No & Percent* \\
\hline 1 & Facebook & 180 & 94.7 \\
\hline 2 & Google+ & 171 & 90 \\
\hline 3 & $2 \mathrm{go}$ & 160 & 84.2 \\
\hline 4 & Skype & 140 & 73.7 \\
\hline 5 & Twitter. & 137 & 72.1 \\
\hline 6 & Library Thing & 111 & 58.4 \\
\hline 7 & Badoo & 80 & 42.1 \\
\hline 8 & LinkedIn & 70 & 36.8 \\
\hline 9 & Classmates & 69 & 36.3 \\
\hline 10 & Myspace & 47 & 24.7 \\
\hline 11 & Academia.edu & 40 & 21 \\
\hline 12 & Bebo & 20 & 10.5 \\
\hline 13 & Foursquare & 20 & 10.5 \\
\hline 14 & LAGbook & 19 & 10 \\
\hline 15 & Delicious & 15 & 7.9 \\
\hline 16 & Social Vibe & 11 & 5.8 \\
\hline 17 & 43 Things & 3 & 1.6 \\
\hline 18 & Flixster & 0 & 0 \\
\hline 19 & Flickr & 0 & 0 \\
\hline 20 & Fledgewing & 0 & 0 \\
\hline 21 & Habbo & 0 & 0 \\
\hline 22 & MyLife (Formerly Reunion) & 0 & 0 \\
\hline 23 & Students circle network & 0 & 0 \\
\hline
\end{tabular}

*Percentage is taken individually in relation to the sample number 
Table 3. How often youths use these social networks

\begin{tabular}{llllllll}
\hline Rank & Items & $*$ V O & O & S & N A & Mean & $\begin{array}{c}\text { Std. } \\
\text { Dev. }\end{array}$ \\
\hline 1 & Facebook & 80 & 90 & 10 & 10 & 3.3 & 1.8 \\
2 & Google+ & 100 & 60 & 11 & 19 & 3.3 & 1.8 \\
3 & 2go & 80 & 60 & 20 & 30 & 3.0 & 1.08 \\
4 & Twitter & 57 & 56 & 44 & 33 & 2.7 & 1.05 \\
5 & Skype & 48 & 59 & 33 & 50 & 2.6 & 1.06 \\
6 & Library Thing & 72 & 30 & 19 & 60 & 2.5 & 1.05 \\
7 & Badoo & 29 & 41 & 10 & 110 & 1.9 & 0.1 \\
8 & Classmates & 19 & 20 & 30 & 121 & 1.7 & 0.1 \\
9 & LinkedIn & 29 & 11 & 30 & 120 & 1.7 & 0.13 \\
10 & Academia.edu & 0 & 40 & 0 & 150 & 1.42 & 0.2 \\
11 & Myspace & 20 & 7 & 20 & 133 & 1.4 & 0.2 \\
12 & Social Vibe & 6 & 5 & 0 & 179 & 1.2 & 0.1 \\
13 & Bebo & 0 & 0 & 20 & 170 & 1.1 & 0.1 \\
14 & Delicious & 0 & 5 & 10 & 175 & 1.1 & 0.1 \\
15 & Foursquare & 0 & 5 & 15 & 170 & 1.1 & 0.1 \\
16 & LAGbook & 0 & 9 & 10 & 171 & 1.1 & 0.1 \\
17 & 43 Things & 0 & 0 & 3 & 187 & 1.01 & 0.1 \\
18 & Flixster & 0 & 0 & 0 & 190 & 1 & 0.1 \\
19 & Flickr & 0 & 0 & 0 & 190 & 1 & 0.1 \\
20 & Fledgewing & 0 & 0 & 0 & 190 & 1 & 0.1 \\
21 & Habbo & 0 & 0 & 0 & 190 & 1 & 0.1 \\
22 & MyLife (Formerly Reunion) & 0 & 0 & 0 & 190 & 1 & 0.1 \\
23 & Students circle network & 0 & 0 & 0 & 190 & 1 & 0.1 \\
\hline
\end{tabular}

$* \mathrm{VO}=$ Very often; $\mathrm{O}=$ Often; $\mathrm{S}=$ Sometimes; $\mathrm{NA}=$ Not at all

Table 4. The purpose of using social networking media

\begin{tabular}{|c|c|c|c|c|c|c|c|}
\hline Rank & Items & \#SA & $\mathbf{A}$ & $\mathbf{D}$ & SD & Mean & $\begin{array}{l}\text { Std. } \\
\text { Dev. }\end{array}$ \\
\hline 1 & For social interaction & 133 & 46 & 03 & 08 & 3.6 & 1.9 \\
\hline 2 & For study, teaching and learning & 150 & 13 & 07 & 20 & 3.5 & 1.9 \\
\hline 3 & Information dissemination & 102 & 60 & 20 & 8 & 3.4 & 1.8 \\
\hline 4 & Research and academic purpose & 110 & 50 & 14 & 16 & 3.3 & 1.8 \\
\hline 5 & For professional networking & 119 & 11 & 30 & 30 & 3.2 & 1.8 \\
\hline 6 & For advertisements & 96 & 60 & 14 & 20 & 3.2 & 1.8 \\
\hline 7 & For fun/entertainment & 06 & 170 & 10 & 04 & 2.9 & 1.7 \\
\hline 8 & For business purposes & 30 & 106 & 04 & 50 & 2.6 & 1.06 \\
\hline 9 & To contribute to government policies & 0 & 100 & 60 & 30 & 2.4 & 1.01 \\
\hline 10 & For political campaigns & 36 & 13 & 120 & 21 & 2.3 & 1.01 \\
\hline 11 & For goal setting and achievement & 08 & 12 & 150 & 20 & 2.0 & 1.0 \\
\hline 12 & For entrepreneurial development & 16 & 30 & 90 & 54 & 2.0 & 1.0 \\
\hline 13 & For employment opportunities & 0 & 68 & 22 & 100 & 1.8 & 0.9 \\
\hline 14 & For charity & 0 & 0 & 50 & 140 & 1.5 & 0.8 \\
\hline 15 & For social bookmarking (save Websites) & 0 & 10 & 50 & 130 & 1.4 & 0.6 \\
\hline
\end{tabular}

\#SA = Strongly agree; A = Agree; $\mathrm{SD}=$ Strongly Disagree; $\mathrm{D}=$ Disagree 
Table 5. Participation of youths on national programmes and policies using social networks

\begin{tabular}{llllllll}
\hline Rank & Item & $*$ V O & O & S & N.A & Mean & $\begin{array}{l}\text { Std. } \\
\text { Dev. }\end{array}$ \\
\hline 1 & & & & & & 1.8 \\
2 & Environmental issues & 133 & 30 & 22 & 05 & 3.5 & 1.8 \\
3 & Health development & 130 & 06 & 48 & 06 & 3.4 & 1.8 \\
4 & Power supply & 101 & 61 & 20 & 08 & 3.3 & 1.8 \\
& Education / Human capital & 109 & 30 & 40 & 11 & 3.2 & 1.8 \\
5 & development & & & & & & \\
6 & Budget monitoring / Evaluation & 116 & 18 & 30 & 26 & 3.2 & 1.8 \\
7 & National security & 110 & 11 & 20 & 49 & 3.0 & 1.7 \\
8 & Job creation / Income generation & 30 & 50 & 30 & 80 & 2.2 & 0.5 \\
9 & Agriculture and food security & 60 & 10 & 07 & 113 & 2.1 & 0.5 \\
10 & Water and sanitation & 0 & 81 & 39 & 70 & 2.1 & 0.5 \\
11 & Oil and gas development & 16 & 80 & 04 & 90 & 1.8 & 0.1 \\
12 & Political integration & 07 & 33 & 66 & 84 & 1.8 & 0.1 \\
13 & Reduction of corruption & 20 & 40 & 21 & 109 & 1.8 & 0.1 \\
\hline
\end{tabular}

$* \mathrm{VO}=$ Very often; $\mathrm{O}=$ Often; $\mathrm{S}=$ Sometimes; $\mathrm{NA}=$ Not at all

Table 6. The extent to which social networking has improved national policies and programmes in Nigeria

\begin{tabular}{llllllll}
\hline Rank & Items & +VHE & HE & LE & VLE & Mean & Std. Dev. \\
& & & & & & & \\
\hline 1 & Education / Human capital & 116 & 60 & 10 & 04 & 3.5 & 1.8 \\
& $\begin{array}{l}\text { development } \\
2\end{array}$ & 119 & 30 & 40 & 01 & 3.4 & 1.8 \\
3 & Health development & 109 & 40 & 30 & 11 & 3.3 & 1.8 \\
4 & Environmental issues & 61 & 101 & 09 & 19 & 3.1 & 1.7 \\
5 & Bower supply & 102 & 18 & 60 & 10 & 3.1 & 1.7 \\
6 & Agriculture and food security & 70 & 0 & 90 & 30 & 2.6 & 1.6 \\
7 & Oil and gas development & 02 & 90 & 90 & 08 & 2.5 & 1.5 \\
8 & Job creation / Income generation & 15 & 20 & 111 & 45 & 2.0 & 0.5 \\
9 & National security & 03 & 17 & 139 & 31 & 2.0 & 0.5 \\
10 & Water and sanitation & 03 & 60 & 70 & 57 & 2.0 & 0.5 \\
11 & Judicial reforms & 0 & 0 & 130 & 60 & 1.7 & 0.1 \\
12 & Reduction of corruption & 18 & 36 & 16 & 120 & 1.7 & 0.1 \\
13 & Political integration & 0 & 11 & 100 & 79 & 1.6 & 0.1 \\
\hline
\end{tabular}

+VHE = Very high extent; HE = High extent; LE = Low extent; VLE = Very low extent

Table 3 summarises how often the respondents used these social networks. It indicates that Nigerian youths used Facebook and Google+ very often with the highest mean scores of 3.3, followed closely by 2 go with a mean score of 3.0. Twitter, Skype and Library Thing had mean scores of 2.5 to 2.7. Badoo, Bebo, Classmates.com, Four Square, Social Vibes, Flixter, Flickr and Fledge wings were not used by the youths.

Table 4 summarises the respondents' level of agreement on the purposes of using social networking media. The respondents strongly agreed that the purpose of using social networks was for social interaction (3.6), study teaching and learning (3.5), information dissemination (3.4), research and academic purposes (3.3), professional networking (3.2) and advertisement 
Table 7. The challenges of social networking in Nigeria

\begin{tabular}{llllllll}
\hline Rank & Items & \#SA & A & D & SD & Mean & $\begin{array}{l}\text { Std. } \\
\text { Dev. }\end{array}$ \\
\hline 1 & Lack of control of activities of users & 176 & 14 & 0 & 0 & 3.9 & 2.0 \\
2 & Power failure & 161 & 20 & 04 & 05 & 3.8 & 1.9 \\
3 & High cost of Internet access & 153 & 20 & 07 & 10 & 3.7 & 1.9 \\
4 & Poor Internet connectivity & 130 & 40 & 15 & 05 & 3.6 & 1.9 \\
5 & Lack of technical know how & 123 & 43 & 15 & 09 & 3.5 & 1.8 \\
6 & Censorships & 40 & 136 & 0 & 14 & 3.1 & 1.7 \\
7 & Lack of awareness of social networks & 63 & 32 & 95 & 0 & 2.8 & 1.6 \\
8 & Lack of authenticity of information & 0 & 151 & 30 & 09 & 2.7 & 1.6 \\
\hline \multicolumn{7}{l}{ \#SA = Strongly agree; A = Agree; SD = Strongly Disagree; D = Disagree } &
\end{tabular}

(3.2). Other purposes of using social networking sites were for fun and entertainment (2.9), for business purposes (2.6), to contribute to government policies (2.4), for political campaigns (2.3), and for entrepreneurial development (2.0). Youths rarely used social networking sites for employment opportunities (1.8), charity (1.5), and social bookmarking (1.4).

Table 5 summarises the responses on the participation of youths in national transformation policies of the federal government. It shows that youths often use social networks to participate in environmental issues (mean score of 3.5), health development (3.4), power supply (3.3), education and human capital development (3.2), budget monitoring and evaluation (3.2), as well as for national security (3.2). Items with particularly low scores below 2.0 were: oil and gas development (1.8), political integration (1.8), reduction of corruption (1.8), and judiciary reform (1.3).

Table 6 summarises the responses on the extent that social networking has improved national programmes and policies in Nigeria. The respondents indicated that there had been remarkable improvement in the following areas: education and human capital development (mean score of 3.5), health development (3.4), environmental issues (3.3), budget monitoring and evaluation (3.1), power supply (3.1), agriculture and food security (2.6), and oil and gas development (2.5). Items that had particularly low scores were: judiciary reforms (1.7), reduction of corruption (1.7) and political integration (1.6).

Table 7 summarises the respondents' level of agreement on the challenges and problems of using social networking in Nigeria. All the items in the table have mean scores above 2.5 , indicating general agreement that they were all challenges of using social networking services in Nigeria.

\section{DISCUSSION OF RESULTS}

The results of this study provide an insight into the use of social networking media among Nigerian youths with special reference to government programmes and policies. The major social networking services used by Nigerian youths were Facebook, 2go, Google+, Skype and Twitter. This is in line with the findings of earlier studies of Burkhardt (2010, as cited in Ekwelem, Okafor \& Ukwoma, 2012), which reported over three hundred thousand active users of Facebook and LinkedIn. It also gives credence to the study of Asogwa and Ojih (2013), which found that major social networking sites used by Nigerian students were Facebook, Twitter and 2go. Riper (2006) and recently Anjum (2014) had earlier found the increasing use of social networking media globally via smart-phones or portable devices which made surfing networks easy and convenient. The vast appeal of these new and 
innovative technologies influences the way teenagers work and interact with others, causing a communication platform shift from an offline to online one.

The findings of the study indicate that the first six social networking services are often used among Nigerian youths. This is not surprising because even outside Nigeria these are the most popular social networking media. This popularity has been reported in the works of the Society for New Communication Research (2009) and Acquisti and Gross (2006). The results of the study also indicate that the main reasons why youths use social media are for social interaction, study, teaching and learning, information dissemination, professional networking academic purposes and for advertisement of social programmes such as birthdays, marriages, and funeral ceremonies. Obviously, participation in government policies and programmes and political campaigns are not the primary purposes of social media use among Nigerian youths. This is contrary to earlier observations by the Society for New Communication Research (2009) and Medimorec, Parycek and Schossböck (2011) that the use of social networking media played major roles in the 2008 US presidential campaign. Perhaps, Nigerian youths have yet to understand the impact of social media in political campaigns and influencing government programmes and policies. The findings are not in line with the positions of Goad, Mooney and Bruns (2008) and Junco, Heibergert and Loken (2010) who had looked at social networking as a platform and practice that support collaboration, community building, information sharing and citizen participation in the decision making process. Thus, Nigerian youths are yet to fully exploit the potential of social networking in national integration and development.

The findings indicate that youths adopt social media to participate in environmental issues, health development, power supply, education/human capital development, budget monitoring/evaluation and national security. Obviously, these are areas that directly or indirectly affect youth development in Nigeria. Youths in the present digital era understand the social value of online activities and are therefore highly motivated to participate in programmes that are likely to improve their condition. This finding relates with earlier studies of Watson (2008) and Abonu (2012), which reported that social media were useful in the promotion of health and social care, and job opportunities. It also supports the assertion of Lenhart, Purcell and Smith. (2010) that social networking can be used in the transformation and delivery of education. It is however a source of worry that the youths hardly adopt the use of social media in job creation, food security, political integration, poverty reduction and judicial reforms. Though these areas may not have a direct impact on youth development, they are equally important issues in national development.

Significant improvements in education, health development, environmental issues, power supply, budget monitoring and agricultural programmes have been observed by the survey respondents. Evidently, since the return of democracy in Nigeria, critical indicators of socio-economic development have improved. Youths' participation in the business of governance may have contributed immensely in these improvements because democracy provides opportunity for cross-pollination of ideas. This gives credence to the position of Goad, Mooney and Bruns (2008) that social networking services provide a platform for the radical transformation of a society since citizens are no longer passive in government activities. Other key areas of government programmes are, however, yet to show significant improvement, as can be seen from the survey responses. These are also areas where youths have not shown enough participation through social media. This is contrary to the views of Medimorec, Parycek and Schossböck (2011) and Milakovich (2010), whom underscored the influence of e-participation in every democratic government, particularly in developing countries. This shortcoming may not be unconnected with the low literacy rate and poor 
information and communication infrastructure in the country. It is a source of worry that after about 15 years of democracy in Nigeria, political integration, judicial reforms, and reduction of corruption, there remain serious challenges to national development. Nigerian youths need to do more in responding to government policies and programmes particularly in these areas.

The use of social media among Nigerian youths is faced with several challenges. The key challenges, as indicated in the survey responses, are the lack of unregulated activities of the users, power failures, the high cost of Internet access, and poor Internet connectivity. Unregulated activities of users appear to pose a major challenge for social networking media in Nigeria. Perhaps Nigeria should emulate the example of the United States by enacting a cyber bullying prevention act as reported by Hanley (n.d). Otherwise, Nigeria may have more serious cases of cyber bullying in future. Such legislation would be critical to reducing cyber crime and bullying associated with social networking media as reported by several authors. Other challenges of social media among Nigerian youths reflect earlier findings on the challenges of ICT in Nigeria, as reported by Ezeani and Ezema (2011), Ezema (2011) and Ezema and Ugwu (2013). This implies that such challenges have not been addressed in the country.

\section{CONCLUSION AND RECOMMENDATIONS}

The transformation agenda of the present administration in Nigeria is intended to improve the socio-economic conditions of the people. Any people-oriented programme of the government requires active participation from the people. The youths that constitute a large proportion of the population have key roles to play in these programmes. Social networking media provide good platforms for effective participation and evaluation of these government programmes.

From the outset, it is evident that Nigerian youths are already actively involved in the use of social networking media for participation in government programmes and policies. Facebook, Twitter and Google+ seem to be the most popular social networking media among Nigerian youths. Obviously, social networking has improved the level of participation of the youths in government programmes and policies. This needs more support not just to sustain the level of participation but to enhance it.

It is however a source of worry that the youths rarely make use of social networking media for active participation in political and anti-corruption campaigns. Nigerian youths can change the political landscape by creating accounts in some of the popular social networking media. This will be useful in canvassing support for people-oriented public policies. Interestingly, the democratic administration in the country has paid attention to public opinion unlike the period of military regime. Though some people have posted obscene and irrelevant material on the Facebook group of "Nationwide Anti Fuel Subsidy Removal: Strategies and Protests" (https://www.facebook.com/groups/occupy.naija/) created in 2012 during the hike in the pump price of petrol in Nigeria, the group assisted immensely in sensitising the people on the need to join the protest. It is likely that posts on the Facebook group informed the government's decision to reduce pump price of petrol during that time. Similarly, the fight against corruption in the country can be made more successful through social networking media. The inability of the youths to use social networking media in political campaign and fight against corruption is an interesting area for further research.

This paper recommends that the government set up a commission that would be responsible for the regulation of all social networking activities in the country. There is a need to provide uninterrupted power supply in the country. The government is already making efforts in this regard, but not much has been accomplished. Internet bandwidths are still very 
low in Nigeria. This is an area where both government and private organisations should step up efforts to ensure that Internet services are available and affordable in the country. To achieve this, the government needs to adopt a public, private partnership (PPP) in the sector.

Awareness should be created on the effect of social media on political activities. The more the youths engage in political campaigns through social networking services, the more political campaigns become robust and issue-based. Though social networking media need to be regulated, they deserve to be encouraged by both government and nongovernmental agencies for their speedy and reliable information dissemination for participatory democracy. Apart from the youths, adults should also be encouraged to use of social networking media to create sustainable citizen participation in government programmes and policies.

\section{REFERENCES}

Abonu, A. D. (2012, August 31). Social media and new ideas for transformation: The David Mark perspective. The Rise Magazine, 3.

Acquisti, A., \& Gross, R. (2006). Imagined communities: awareness, information sharing and privacy protection on the Facebook. In Proceedings from the 6th Workshop on Privacy Enhancing Technologies, Cambridge, UK.

Adesiyan, W. (2012). Abia State University gang rape video causes nationwide rage. Retrieved from www.searchnigeria.net/articles/index.php?page=view\%2Farticle\% 2F3844\%2FAbia-State-University-Gang-Rape-Video-Causes-Nationwide-Rage

Adeyemi, A. (2012, September 20). Expanding IT networks for national transformation. The Guardian. Retrieved from http://www.guardiannewsngr.com/index.php?

African Community Publishing and Development Trust. (2006). Reviving our hopes: Community view on poverty and economic survival. Cape Town: African Community Publishing and Development Trust.

Aharony, N. (2012). Twitter use by three political leaders: An exploratory analysis. Online Information Review, 36(4), 587-603. http://dx.doi.org/10.1108/14684521211254086

Akindehin, F., \& Akindehin, M. (2011). Online social networking practices of some Nigerian university undergraduates: Implications for counselling. British Journal of Arts and Social Sciences, 3(1). Retrieved from http://www.bjournal.co.uk/BJASS.aspx

Anderson, T. (2005). Distance learning —Social software's killer app? In Proceedings from Conference of the Open and Distance Learning Association of Australia (ODLAA). Adelaide: University of South Australia.

Anjum, Z. I. (2014). Risk of cybercrime and social media. Retrieved from www.crigroup.com/wp.../risks-of-cybercrime-and-social-media-web-.pdf

Arnstein, S. R. (1969). A ladder of citizen participation. Journal of the American Planning Association, 35(4), 216-224.

Asogwa, C. E., \& Ojih, E. U. (2013). Social networking sites as tools for sexual perversion among students of University of Nigeria, Nsukka. New Media and Mass Communication, 9, 27-38. Retrieved from www.iiste.org

Brennan, M. (2006). Understanding online social network services and risks to youth. London: Child Exploitation and Online Protection.

Bronstein, J. (2013). Like me! Analyzing the 2012 presidential candidates' Facebook pages. Online Information Review, 37(2), 173-192. http://dx.doi.org/10.1108/OIR-01-20130002 
Bryer, T., \& Zavattaro, S. (2011). Social media and public administration: Theoretical dimensions and introduction to symposium. Administrative Theory \& Practice, 33(3), 325-340.

Burkhardt, A. (2010). Social media: A guide for college and university libraries. College \& Research Libraries News, 71(1), 10-24. Retrieved from http://crln.acrl.org/content/71/1/10

Burns, D., Hambleton, R., \& Hoggett, P. (1994). The politics of decentralization. London: Macmillan.

Canadian Nurses Association. (2012). When private becomes public: The ethical challenges and opportunities of social media. Ethics in Practice for Registered Nurses. Retrieved from https://www.cnaaiic.ca/ /media/cna/page\%20content/pdf\%20en/2013 /07/26/10/43/ ethics_in_practice_feb_2012_e.pdf

Chikerema, A. F. (2013). Citizen participation and local democracy in Zimbabwean local government system. IOSR Journal of Humanities and Social Science, 13(2), 87-90. Retrieved from www.iosrjournals.org

Creswell, J. W. (2003). Research design: Qualitative, quantitative, and mixed method approaches (2nd ed.). London: Sage Publications.

Daou, P. (2008). The revolution of the online commentariat. Retrieved from http://publius. cc/2008/12/09/the-revolution-of-the-online-commentariat/

Davies, C. (2010). We are what we post: Social media and identity creation. Retrieved from http://catherineadavis.tumblr.com/post/4783520985/we-are-what-we-post-socialmedia- And-identity-creation

Ekwelem, V., Okafor, V. N., \& Ukwoma, S. C. (2012). Use of social networking sites by Nigerian librarians: An exploratory study. In Proceedings from the 12th Annual Conference/Annual General Meeting of Nigeria Library Association (NLA) Enugu State Chapter (pp. 118-126). Enugu: Nigeria Library Association.

Ellison, N. B., \& Boyd, D. M. (2007). Social network sites: Definition, history, and scholarship. Journal of Computer-Mediated Communication, 13(1). Retrieved from http://jcmc.indiana.edu/vol13/issue1/boyd.ellison.html

Epstein, R. A. (2011). Direct democracy: Government of the people, by the people, and for the people. Harvard Journal of Law \& Public Policy, 34, 821-826. Retrieved from chicagounbound.uchicago.edu/cgi/viewcontent.cgi?article $=2260$

Ezeani, C. N., \& Ezema, I. J. (2011). Digitizing institutional research output of University of Nigeria, Nsukka. Library Philosophy and Practice. Retrieved from http://unllib.unl.edu/LPP/

Ezema, I. J. (2011). Building open access institutional repositories for global visibility of Nigeria scholarly publications. Library Review, 60(6), 473-485.

Ezema, I. J., \& Ugwu, C. I. (2013). Electronic theses and dissertations in Nigerian university libraries: challenges and strategies. The Electronic Library, 31(4), 496-507. Retrieved from www.emeraldinsight.com/0264-0473.htm

Gaventa, J., \& Valderrama, C. (1999). Participation, citizenship and local governance. Background note prepared for workshop on "Strengthening participation in local governance." Retrieved from http://www.uv.es/ fernandm/Gaventa,\%20Valderrama.pdf

Goad, R., Mooney, T., \& Bruns, V. (2008). The impact of social networking in the UK. Retrieved from http://www.melcarson.com/wp.content/uploads2008/01/hitwise-soccialnetworkingreport-2008.pdf 
Hanley, J.A. (n.d). Cyberbullying - a global concern. Family Online Safety Institute. Retrieved from http://www.wvisd.net/cms/lib/TX01001412/Centricity/Domain/12/cyberbullying.pdf

Junco, R., Heibergert, G., \& Loken, E. (2010). The effect of Twitter on college student engagement and grades. Journal of Computer Assisted Learning, 27(2), 119-132. doi: 10.1111/j.1365-2729.2010.00387.x

Khan, G. F., Yoon, H. Y., Kim, J., \& Park, H. W. (2014). From e-government to social government: Twitter use by Korea's central government. Online Information Review, 38(1), 95-113. http://dx.doi.org/10.1108/OIR-09-2012-0162

Kim, J., Lee, C., \& Elias, T. (2015). Factors affecting information sharing in social networking sites amongst university students. Online Information Review, 39(3), 290309. http://dx.doi.org/10.1108/OIR-01-2015-0022

Lenhart, A., Purcell, K., \& Smith, A. (2010). Social media and young adults. Washington: Pew Research Centre.

Macintosh, A. (2006). E-participation in policy-making: the research and the challenges. In P. Cunningham \& M. Cunninghan (Eds.), Exploiting the knowledge economy: Issues, applications and case studies (pp. 364-369). Amsterdam: IOS Press.

Medimorec, D., Parycek, P., \& Schossböck, J. (2011). Vitalizing democracy through eparticipation and open government: an Austrian and Eastern European perspective. Retrieved from http://www.bertelsmann-stiftung.de/cps/rde/xbcr/SID-9CAA7CF5908C191E/bst/Daniel\%20Medimorec.pdf

Milakovich, M. E. (2010). The Internet and increased citizen participation in government. $E$ Journal of e-Democracy, 2(1). Retrieved from http://www.jedem.org

National Bureau of Statistics. (2010). National manpower stock and employment generation survey: Household and Micro Enterprise - July 2010 [Data file]. Retrieved from www.nigerianstat.gov.ng/pages/download/41

National Planning Commission Abuja. (2011). Annual progress report of country's economic performance. Retrieved from http://www.npc.gov.np/new/eng/index.php

Nwafor, M. C, Igbokwe, P. C., \& Ugwuanyi, R. N. C. (2012). Social networking and national transformation: Issues, challenges and implications. In Proceedings of $12^{\text {th }}$ Annual Conference of Nigeria Library Association (NLA), Enugu State Chapter, Enugu, 21-23 November (pp. 222-228).

Parry, G., Mosley, G., \& Day, N. (1992). Political participation and democracy in Britain. Cambridge: Cambridge University Press.

Pettit, J., Salazar, J. F., \& Dagron, A. G. (2009). Citizens' media and communication. Development in Practice, 19(4\&5), 443-452.

Ramanigopal, C. S., Palaniappa, G., \& Hemalatha, N. (2012). Social networking: problems and prospects of knowledge society. International Journal of Research in Management, Economics and Commerce, 2(2), 116-129. Retrieved from www.indsedu.org

Riper, T. (2006). Brand me. Retrieved from http://www.forbes.com/2006/02/08/pepsi-nikethreadless-cx_tvr_0209teenbrands.html

Safranek, R. (2012). The emerging role of social media in political and regime change.

ProQuest Discovery Guides. Retrived from http://www.csa.com/discoveryguides/discoveryguides-main.php

Society for New Communication Research. (2009). Social media and the 2008 U.S. Presidential Election. Washington: Study by the Society for New Communications Research. Retrieved from 
http://sncr.org/sites/default/files/2008_election_and_social_media_REV20100301R2ar _BRIEF.pdf

Sund, C. (2007). Towards an international road-map for cybersecurity. Online Information Review, 31(5), 566-582. http://dx.doi.org/10.1108/14684520710832306

Thelwall, M. (2008). Social networks, gender and friendship: An analysis of MySpace member profiles. Journal of the American Society for Information Science and Technology, 59(8), 1321-1330.

Topper, E. F. (2007). What's new in libraries: social networking in libraries. New Library World, 108(7\&8), 378-380. Retrieved from www.emeraldinsight.com/0307-4803.htm

University of Illinois at Urbana-Champaign. (2007, November 8). Benefits of online interaction for teens outweigh danger, professor says. Science Daily. Retrieved from www.sciencedaily.com/releases/2007/11/071106133103.htm

Virkus, S. (2008). Use of Web 2.0 technologies in LIS education: Experiences at Tallinn University, Estonia Program. Electronic Library and Information Systems, 42(3), 262274. Retrieved from www.emeraldinsight.com/0033-0337.htm

Watson, M. (2008). Social networking: an opportunity for health and social care? Journal of Integrated Care, 16(1), 41-43.

Williams, C. (2007). Research methods. Journal of Business and Economic Research, 5(3), 65-72.

World Bank. (1996). The World Bank participation source book. Washington: World Bank. 